\title{
Reign lists for the rulers of Gowa and Talloq
}

Rulers of Gowa to 1753

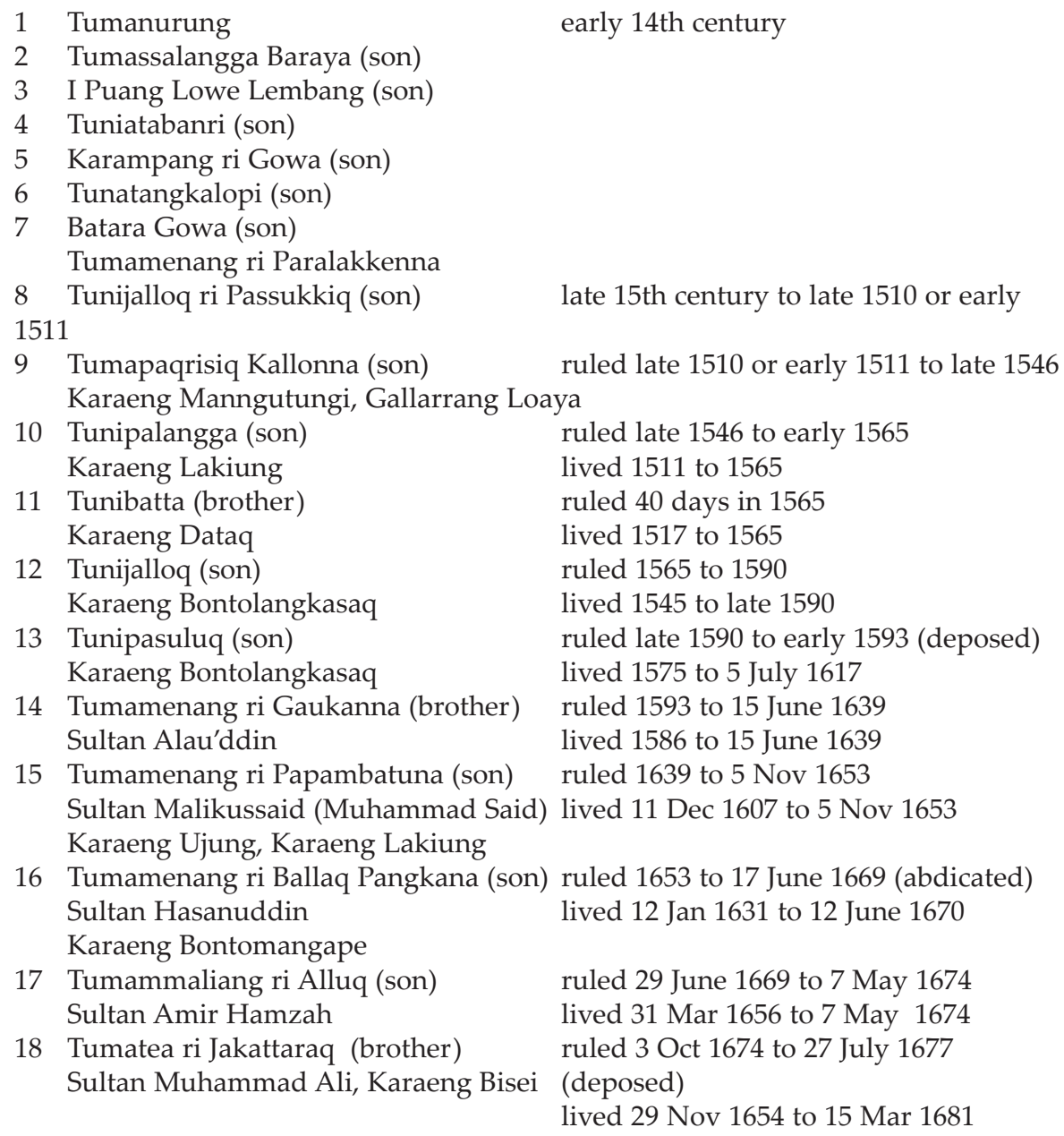


19 Tumamenang ri Lakiung (brother) ruled 27 July 1677 to 17 Sept 1709 Sultan Abdul Jalil, Karaeng Sanrabone lived 18 Aug 1652 to 17 Sept 1709

20 Tumamenang ri Sombaopu (grandson) ruled 21 Sept 1709 to 24 Aug 1712 Sultan Ismail, Karaeng Anaq Moncong (deposed)

lived 18 Jan 1690 to 1 Apr 1724

21 Tumamenang ri Pasiq (son of T11) Karaeng Kanjilo ruled 31 Aug 1712 to 5 Nov 1735 (abdicated)

Sultan Sirajuddin, Tumamaliang ri Talloq

22 Tumamenang ri Gowa (grandson of G21, son of T14) Sultan Abdul Khair Almansyur I Mallawanggauq

23 Karaeng Bontolangkasaq lived 14 Mar 1694 to 8 Sept 1739

24 Tumamenang ri Kalabiranna (brother of G22)

Sultan Abdul Kudus lived 17 Nov 1687 to 22 Jan 1739 ruled 5 Nov 1735 to 28 July 1742 lived 12 Feb 1727 to 28 July 1742 ruled 10 April 1739 to 8 Sept 1739 ruled 28 July 1742 to 1753 lived Dec 1733 to 1753

1 Karaeng Lowe ri Sero (son of G6)

2 Tunilabu ri Suriwa (son)

3 Tunipasuruq, Karaeng ri Passiq (son)

4 Tumenanga ri Makkoayang (son) Karaeng Pattingalloang

5 Karaeng Bainea (daughter)

Karaeng Pattingalloang

6 Tunipasuluq (son)

7 Karaeng Matoaya (son of T4) Sultan Abdullah, Tumamenang ri Agamana

Karaeng Kanjilo, Karaeng Segeri

8 Karaeng Kanjilo (son)

Sultan Mudhaffar

Tumammaliang ri Timoroq

9 Karaeng Pattingalloang (brother) Sultan Mahmud Tumamenang ri Bontobiraeng

10 Tumamenang ri Lampana (son of T8) Sultan Harrunarasyid

11 Tumamenang ri Passiringanna (son) Sultan Abdul Kadir

12 Tumamenang ri Pasiq, Karaeng Kanjilo (son)

Sultan Sirajuddin, Tumamaliang mid to late 15th century late 15 th century to $1500 \mathrm{~s}$ 1500 s to 1540 or 1543 ruled 1540 or 1543 to 1576 lived 1520 to 1576 late 1576 to 1590

late 1590 to early 1593 ruled 1593 to 1623 (advised son to 1636) lived 1573 to 1636

ruled 1623 to 18 May 1641 lived 1598 to 18 May 1641

ruled 1641 to 15 Sept 1654 lived Aug 1600 to 15 Sept 1654

ruled 1654 to 16 June 1673 lived 3 Nov 1640 to 16 June 1673 ruled 1673 to 8 Jan 1709 lived 7 Jan 1666 to 8 Jan 1709 ruled 12 Aug 1709 to 1714 ruled 25 Apr 1729 to 1739 
ri Talloq

13 Tumamenang ri Jawaya (son) Sultan Najamuddin

14 Karaeng Lempangang (brother) Syafiuddin lived 17 Nov 1687 to 22 Jan 1739

ruled 1714 to 24 Apr 1729

lived 23 Dec 1708 to 24 Apr 1729

ruled 1739 to 1760

lived 7 Dec 1709 to 1760 